\title{
PENGARUH VARIASI INFEKSI MALARIA TERHADAP POSITIVITAS PROTEIN URINE PADA PENDERITA MALARIA
}

\author{
Dendi Arisandi ${ }^{1}$, Erlin Yustin Tatontos ${ }^{2}$, Urip ${ }^{3}$ \\ ${ }^{1-3}$ Jurusan Analis Kesehatan, Poltekkes Kemenkes Mataram, Indonesia.
}

\section{Article Info}

Article history:

Received Mei $23^{\text {th }}, 2019$

Revised Jun $18^{\text {th }}, 2019$

Accepted Jul 20 ${ }^{\text {th }}, 2019$

Keywords :

Malaria sufferer,

positivity of urine protein, variations in malaria infection

\begin{abstract}
Malaria is an infectious disease caused by parasites. The entry of malaria can be known by one of them with an increase in protein in the urine. Protein levels in the urine of more than $150 \mathrm{mg}$ can be found in glomerular capillary membrane defects or due to disruption of the mechanism of tubular reabsorption or damage to both mechanisms. To determine the effect of variations in malaria infection on positivity of urine protein in malaria patients. This study was an observational analytic study with a cross sectional approach, the number of samples using saturated samples, sampling techniques using accidental sampling, research variables in the form of variations in malaria infection and positivity of urine protein. The types of malaria that infect many of the working areas of Meninting Health Center and Penimbung Health Center are Falciparum Malaria (Malaria Tropics) Malaria Vivaks (Tertiana Malaria) and Mix Malaria with positivity of urine proteins differing. Chi Square test results show $p=0.892$ because the probability is more than 0.05 $(p<\alpha=0.05)$ means that Ho is accepted and Ha is rejected. There is no effect of variations in malaria infection on positivity of urine protein in malaria patients.
\end{abstract}

Copyright $\odot$ Jurnal Analis Medika Bio Sains All rights reserved.

\begin{abstract}
ABSTRAK
Malaria merupakan penyakit infeksi yang disebabkan oleh Parasit. Masuknya penyakit malaria dapat diketahui salah satunya dengan adanya peningkatan protein pada urine. Kadar protein dalam urin lebih dari $150 \mathrm{mg}$ dapat dijumpai pada kerusakan- kerusakan membran kapiler glomerulus atau karena gangguan mekanisme reabsorbsi tubulus atau kerusakan-kerusakan pada kedua mekanisme tersebut. Penelitian ini untuk mengetahui pengaruh variasi infeksi malaria terhadap positivitas protein urine pada penderita malaria. Penelitian ini merupakan penelitian yang besifat observasional analitik dengan pendekatan cross sectional, jumlah sampel menggunakan sampel jenuh, teknik pengambilan sampel dengan cara Accidental Sampling, variabel penelitian berupa variasi infeksi malaria dan positivitas protein urine. Jenis malaria yang banyak menginfeksi di wilayah kerja Puskesmas Meninting dan Puskesmas Penimbung adalah Malaria Falsiparum (Malaria Tropika) Malaria Vivaks (Malaria Tertiana) dan Malaria Mix dengan positivitas protein urine berbeda beda. Hasil uji Chi Square menunjukkan $\mathrm{p}=0,892$ Karena probabilitas lebih dari $0,05(\mathrm{p}<\alpha=0,05)$ artinya Ho diterima dan Ha di tolak. Tidak ada pengaruh variasi infeksi malaria terhadap positivitas protein urine pada penderita malaria
\end{abstract}

Kata Kunci : penderita malaria, positivitas protein urine, variasi infeksi malaria 


\section{Pendahuluan}

Malaria merupakan penyakit infeksi yang disebabkan oleh Parasit Genus Plasmodium terdiri dari 4 spesies yaitu Plasmodium vivax, Plasmodium falciparum, Plasmodium malariae, plasmodium ovale, dan plasmodium mix. Penularan malaria melalui nyamuk anopheles yang telah terinfeksi parasit malaria. Infeksi malaria memberikan gejala berupa demam, menggigil, anemia dan ikterus (Harijanto, 2006).

Indonesia adalah negara tropis yang sangat cocok untuk berkembang biaknya vektor nyamuk terutama nyamuk Anopheles, bahkan di luar Pulau Jawa dan Bali dinyatakan daerah endemis malaria. Secara nasional angka kesakitan malaria selama tahun 2005-2015 cenderung menurun yaitu dari 4,1 per 1.000 penduduk berisiko pada tahun 2005 menjadi 0,85 per 1.000 penduduk berisiko pada tahun 2015. Sementara target Rencana Strategi Kementerian Kesehatan (Renstra) untuk angka kesakitan malaria Annual Parasite Incidence (API) pada tahun 2015, kurang dari 1 per 1.000 penduduk berisiko. Dengan demikian angka cakupan API 2015 mencapai target Renstra 2015 (Kemenkes RI 2015).

Parasit yang masuk dalam tubuh melalui gigitan nyamuk Anopheles yang terifeksi (sporozoid) akan menginfeksi sel di hati dan akan melakukan replikasi aseksual menjadi schizon, schizon akan pecah dan menghasilkan banyak merozoid. Merozoid selanjutnya akan menyebar ke dalam aliran darah dan menginfeksi sel darah merah, pada Plasmodiumn vivax dan Plasmodium ovale tidak semua parasit menyebar ke aliran darah ada yang dorman di hati dan dapat aktif kembali. Sehingga kalau hati mengalami kerusakan maka akan berpengaruh terhadap kadar protein.

Masuknya penyakit malaria dapat diketahui salah satunya dengan adanya peningkatan protein pada urine. Kadar protein dalam urin lebih dari $150 \mathrm{mg}$ dapat dijumpai pada kerusakan- kerusakan membran kapiler glomerulus atau karena gangguan mekanisme reabsorbsi tubulus atau kerusakan-kerusakan pada kedua mekanisme tersebut. Protein ini dapat terjadi karena GFR (Glomerulus Filtration Rate) atau laju filtrasi glomerulus yang meningkat karena kelainan basal membran glomerulus. Kelainan tubulus atau karena perubahan protein sehingga mudah difiltrasi misalnya pada multiple meloma (Yenny, 2016).

Penelitian ini bertujuan untuk mengetahui pengaruh variasi infeksi malaria terhadap positivitas protein urine pada penderita malaria.

\section{Metode Penelitian}

Penelitian ini menggunakan metode observasional analitik yaitu Jenis atau rancangan penelitian ini adalah observasional analitik dengan menggunakan pendekatan cross sectional. Metode penelitian dengan pendekatan cross sectional (potong lintang) yaitu rancangan penelitian dengan melakukan pengukuran atau pengamatan pada saat bersamaan atau sekali waktu (Hidayat, 2007).

Teknik pengambilan sampel dari penelitian ini adalah dengan cara Accidental Sampling yaitu mengambil kasus atau responden yang kebetulan ada atau tersedia di suatu tempat sesuai dengan konteks penelitian (Notoatmodjo, 2012).

Data yang diperoleh dianalisis untuk melihat adanya pengaruh variasi infeksi malaria yang disebabkan oleh Plasmodium Falciparum, Plasmodium Vivax, dan campuran Plasmodium (mix), untuk data kualitatif dianalisis menggunakan uji Non Parametrik Chi-Square pada tingkat kepercayaan 95\% p $\alpha=0,05$ dengan bantuan komputer program SPSS. Untuk data semi kuantitatif menggunakan perkiraan kadar atau range kadar maka dianalisa secara deskriptif

\section{Hasil Penelitian dan Pembahasan}

Hasil positivitas protein urine secara kualitatif dan semi kuantitatif dengan menggunakan metode carik celup pada penderita malaria. Hasil penelitian yang dilakukan pada bulan Maret 2019 hingga Mei 2019 didapatkan jenis malaria terhadap positivitas protein urine dilihat pada tabel 4.1 
Tabel 4.1. Data hasil positivitas protein urine secara kualitatif dan semin kuantitatif dengan metode carik celup pada penderita infeksi malaria

\begin{tabular}{|c|c|c|c|c|c|}
\hline \multirow{2}{*}{ No } & \multirow{2}{*}{ Jenis Malaria } & \multicolumn{2}{|c|}{ Kualitatif } & \multicolumn{2}{|c|}{ Semi Kuantitatif } \\
\hline & & $\begin{array}{l}\mathrm{Ka} \\
\text { dar }\end{array}$ & $\%$ & $\begin{array}{c}\text { Kadar } \\
(\mathrm{g} / \mathrm{dl})\end{array}$ & $\%$ \\
\hline 1. & Plasmodium Vivax & - & & - & \\
\hline 2. & Plasmodium Vivax & +2 & 25 & $0.05-0.2$ & 25 \\
\hline 3. & Plasmodium Vivax & +3 & & $0.2-0.5$ & \\
\hline 4. & Plasmodium Falciparum & +3 & & $0.2-0.5$ & \\
\hline 5. & Plasmodium Falciparum & +2 & 33 & $0.05-0.2$ & 33 \\
\hline 6. & Plasmodium Falciparum & +2 & & $0.05-0.2$ & \\
\hline 7. & Plasmodium Falciparum & - & & - & \\
\hline 8. & Plasmodium Mix & - & & - & \\
\hline 9. & Plasmodium Mix & - & & - & \\
\hline 10. & Plasmodium Mix & +3 & 42 & $0.2-0.5$ & 42 \\
\hline 11. & Plasmodium Mix & +2 & & $0.05-0.2$ & \\
\hline 12. & Plasmodium Mix & +1 & & $0.01-0.05$ & \\
\hline
\end{tabular}

Dilihat dari tabel 4.1 menunjukkan dari 12 responden didapatkan 3 Plasmodium Vivax, 4 Plasmodium Falciparum, dan 5 Plasmodium Mix. Dengan masing masing persentase yaitu Plasmodium Vivax sebanyak 25\%, Plasmodium Falciparum sebanyak 33\% dan Plasmodium Mix sebanyak 42\%

Tabel 4.2. Uji Chi-Square

\begin{tabular}{|l|r|r|r|}
\hline & Value & Df & Asymp. Sig. (2-sided) \\
\hline Pearson Chi-Square & $2.283^{\mathrm{a}}$ & 6 & .892 \\
Likelihood Ratio & 2.634 & 6 & .853 \\
Linear-by-Linear Association & .338 & 1 & .561 \\
N of Valid Cases & 12 & & \\
\hline
\end{tabular}

Berdasarkan tabel 4.2 setelah di uji statistik menggunakan uji Chi-Square dari 12 responden yang dijadikan sampel diperoleh probabilitas variasi infeksi malaria terhadap positivitas protein urine adalah 0,892. Karena probabilitas lebih dari $0,05(\mathrm{p}<\alpha=0,05)$ artinya Ho diterima dan Ha di tolak hal ini menunjukan bahwa tidak ada pengaruh variasi infeksi malaria terhadap positivitas protein urine. Menurut Penelitian yang dilakukan oleh Mohamed dkk pada tahun 2018 (Mohamed dkk,2018) menyatakan bahwa protein pada urine Histidine Rich Protein 2 HRP2 dapat menentukan adanya infeksi malaria. Namun, Jumlah 
sampel yang sedikit pada penelitian ini juga dapat menyebabkan tidak ada Pengaruh variasi infeksi malaria terhadap positivitas protein urine (Lapau, 2012).

\section{Kesimpulan}

Jenis malaria yang banyak menginfeksi di wilayah kerja Puskesmas Meninting dan Puskesmas Penimbung adalah Malaria Tropika, Malaria Tertiana, Malaria Mix. Hasil positivitas protein urine pada penderita malaria yang disebabkan oleh Plasmodium Vivax sebanyak 3 responden. Hasil positivitas protein urine pada penderita malaria yang disebabkan oleh Plasmodium Falciparum sebanyak 4 responden. Hasil positivitas protein urine pada penderita malaria yang disebabkan oleh Plasmodium Mix sebanyak 5 responden. Dengan Hasil uji statistic Chi-Square yaitu dengan probabilitas sebanyak 0,892 yang berarti bahwa tidak ada pengaruh variasi infeksi malaria terhadap positivitas protein urine pada penderita malaria

\section{Daftar Pustaka}

1. Harijanto. (2006). Buku Ajar Ilmu Penyakit Dalam.

2. Hidayat A.A. (2007). Metode Penelitian Keperawatan dan Teknik Analisa Data. Salemba Medika.

3. Kemenkes RI. (2015). Profil Kesehatan Indonesia. Kementerian Kesehatan Republik Indonesia.

4. Notoatmodjo, S. (2012). Metode Penelitian Kesehatan. Jakarta: Rineka Cipta.

5. Y, H. (2016). Perbedaan Protein Urin Metode Carik Celup Dan Metode Pemanasan Dengan Asam Asetat 3\% Pada Penderita Gagal Ginjal. Akademi Analis Kesehatan 17 AGUSTUS 1945 Semarang. 